University of Chicago Law School

Chicago Unbound

Journal Articles

Faculty Scholarship

1995

\title{
History Lean: The Reconciliation of Private Property and Representative Government
}

Richard A. Epstein

Follow this and additional works at: https://chicagounbound.uchicago.edu/journal_articles

Part of the Law Commons

\section{Recommended Citation}

Richard A. Epstein, "History Lean: The Reconciliation of Private Property and Representative Government," 95 Columbia Law Review 591 (1995).

This Article is brought to you for free and open access by the Faculty Scholarship at Chicago Unbound. It has been accepted for inclusion in Journal Articles by an authorized administrator of Chicago Unbound. For more information, please contact unbound@law.uchicago.edu. 


\title{
HISTORY LEAN: THE RECONCILIATION OF PRIVATE PROPERTY AND REPRESENTATIVE GOVERNMENT
}

\author{
Richard A. Epstein*
}

\section{A Spare Use of History}

The question of proper interpretation is a constant theme of legal analysis. The problems can arise with ordinary contracts, with statutes and administrative rules, and of course, with constitutions, including our own. Martin Flaherty's examination of three possible theories of constitutional interpretation ${ }^{1}$ - those of Bruce Ackerman, Cass Sunstein, and myself-adds an instructive chapter to the ongoing debate over the proper understanding of our own Constitution. His critique of my work targets two of my writings on property rights and economic liberties-my article, "Toward a Revitalization of the Contract Clause," 2 and my book Takings $^{3}$-while ignoring other writings in which I make somewhat greater use of historical sources. ${ }^{4}$ His learned attack sounds a theme familiar to many historians: the unruly complexity of historical experience cannot be accurately or fully captured in a few pet phrases, and it is not possible to do justice to the historical sources by using history to avoid the need for historical inquiry. ${ }^{5}$ Rather, the historian should read widely in the literature and dig hard at the primary sources in order to make sense of the cross currents of political and social thought that molded the Constitution.

His insistence upon this method stands in sharp contrast to my own preferred view of constitutional interpretation, one that lays little stress upon the historical debates that led up to the adoption of the Constitution, and directs far more attention to specific constitutional language and to overall constitutional structure. In taking this position, I have no desire to suppress evidence that is hostile to my position, or to rely on evidence that selectively bolsters that position, some of which is presented

* James Parker Hall Distinguished Service Professor of Law, The University of Chicago. I should like to thank David Currie and Michael McConnell for their helpful comments on earlier drafts of the paper. Martin Flaherty and I have had an instructive exchange of drafts, from which I have also profited.

1. See Martin Flaherty, History "Lite" in Modern American Constitutionalism, 95 Colum. L. Rev. 523 (1995).

2. Richard A. Epstein, Toward a Revitalization of the Contract Clause, 51 U. Chi. L. Rev. 703 (1984) [hereinafter Epstein, Revitalization].

3. Richard A. Epstein, Takings: Private Property and the Power of Eminent Domain (1985) [hereinafter Epstein, Takings].

4. See, e.g., Richard A. Epstein, The Classical Legal Tradition, 73 Cornell L. Rev. 292 (1988); Richard A. Epstein, Modern Republicanism - or the Flight from Substance, 97 Yale L.J. 1633 (1988); Richard A. Epstein, The Proper Scope of the Commerce Power, 73 Va. L. Rev. 1387 (1987).

5. See Flaherty, supra note 1, at 523-26, passim. His neat phrase is "Epstein also relies on history to avoid history." Id. at 558. 
by Flaherty. ${ }^{6}$ Rather, I fear that history offers us too much information, without the means of sorting it out. The best evidence of those historical views that won out are those found in the Constitution itself. Where the consensus is clear, the intended meaning can be found in ordinary words as understood in the popular discourse of the time.

In this brief comment, I respond to Flaherty's criticism in two parts. In Part II, I show one way-the just compensation compromise-in which the Constitution reconciles the twin requirements of private property and political representation. In Part III, I argue that the history to which Flaherty alludes is generally consistent with this overarching theme.

\section{Reconciling Private Property and Political Participation}

Flaherty's paper is methodologically rigorous but substantively neutral. In particular, it does not address the central question of how best to reconcile private property with representational government in a moral universe that could recoguize no place for royal power, let alone the divine right of kings. In the absence of any royal pedigree for private property, that institution had to be justified under theories of natural right or utilitarian advantage. Simultaneously, it became necessary to find out how individuals, once blessed with individual rights to liberty and property, could come together to make collective decisions for the common good. Unfortunately, there is no single answer that can be given to this question, for it is possible to devise schemes that vary from unwieldy systems of direct participation of all citizens in public affairs, to rules imposing property qualifications for the franchise, to complex systems of representation that include divided authority and supermajority provisions. ${ }^{7}$ Not unexpectedly, the debate over the Founding period was highly fluid, and as Flaherty notes, some experiments, such as that conducted in Pennsylvania, travelled quite far down the road toward radical republican thought, only to be doubted and modified in the critical period from 1776 to 1789.8

These two strands of thought could not continue to run indefinitely in parallel. Sooner or later someone would have to decide how to reconcile the protection of private property with the power of representative government. That problem is evident in Locke's treatise, for while Chap-

6. See infra text accompanying notes 33-37.

7. The studied effort to divide authority between the federal and state governments on this problem is reflected in U.S. Const. art. I, $\S 2, \mathrm{cl} .1,2 ; \S 4, \mathrm{cl}$. 1 . The former clause deals with the qualification of electors, and the latter with the "Times, Places and Manner" of holding elections.

8. "[Pennsylvania's] 1776 constitution featured, among other stratagems: a powerful unicameral legislature; a weak multiple executive; a dependent judiciary; annual elections; rotation in office; even a requirement that pending bills be posted on the statehouse door to facilitate public discussion." Flaherty, supra note 1 , at 576 . 
ter Five speaks "Of Property," Chapter Eleven speaks "Of the Extent of the Legislative Power," and makes this critical accommodation:

$\S 138$ Thirdly, The Supreme Power cannot take from any Man any part of his Property without his own consent. For the preservation of Property being the end of Government, and that for which Men enter into Society, it necessarily supposes and requires, that the People should have Property, without which they must be supposed to lose that by entering into Society, which was the end for which they entered into it, too gross an absurdity for any Man to own. ${ }^{9}$

A moment's reflection shows the weakness of this magisterial solution. The last phrase of the first sentence, "his own consent," makes it appear as though the individual can, individually, hold out against the demands of government. Locke does not allow the majority to take property from its members, and hence leaves uncertain the question of how the state can acquire the means to discharge its central function, the protection of property, understood by Locke to mean "his Life, Liberty and Estate." 10 Locke, therefore, quickly switches ground and in the next paragraph reasserts that "the prince or Senate, however it may have power to make Laws for the regulation of Property between the Subjects one amongst another, yet can never have a Power to take to themselves the whole or any part of the Subjects Property, without their own consent."11 So the majority may rule after all, and thus may confiscate the wealth of the minority for its own benefit, a result that is as unpalatable to us as it was to Locke.

The issue then is how to avoid the risks of hold-out when individual consent is required to take property, and the risk of expropriation, when majority consent is allowed to suffice. The Takings Clause in the Fifth Amendment (which tracks the language of Blackstone nicely, ${ }^{12}$ and the practice of English Parliaments) split the difference: the state could take property, but only for public use and upon payment of just compensation. The majority may call the tune, but it has to dance to the tune that it has called.

No amount of historical roaming or romanticizing about the Founding can negate the Lockean influence on the Takings Clause. Yet to note the connections is not to make the Constitution into a simple paean to

9. John Locke, Second Treatise, in John Locke, Two Treatises of Government § 138, at 406 (Cambridge Univ. Press 1960) (1688).

10. Id. $\$ 87$, at 367 . The gist of that phrase is picked up in the speech of Luther Martin in Philadelphia, who refers to how individuals must look to state sovereigns "for the security of their lives, liberties, \& properties." Herbert J. Storing, What the Anti-Federalists Were For 15 (1981). A Lockean influence was evident throughout the Founding period. "The contract and natural-right theories of John Locke were repeatedly iterated without reference to their source." Forrest McDonald, Novus Ordo Seclorum: The Intellectual Origins of the Constitution 7 (1985).

11. Locke, supra note $9, \S 139$, at 407 .

12. See infra text accompanying notes 17-18. 
John Locke, for a subtle but profound shift in orientation comes with the substitution of the words "without just compensation" for "without his own consent." In this new, constitutional regime, the state's ability to force the surrender of property, but by purchase and not by expropriation, negates the holdout power of the individual. By the same token, the compensation requirement counterbalances the monopoly power of the state. The eminent synthesis creates some stringent protection for property rights, but it expressly states that, for public purposes at least, property rights are not absolute but may be overridden for public use on payment of just compensation.

This compromise position is not inconsistent with a considered view of republican thought. The word "republican" comes from the Latin res publicae, or literally, public affairs. As is well shown by M.N.S. Sellers, the Latin origin of the term is fully consistent with the extensive reliance on Roman ideals and Roman sources throughout the Founding period. ${ }^{13}$ So much is evident in the fact that the fictional author of The Federalist is Publius, and countless other authors took the names of Roman thinkers to express their own view, or described themselves in ways (e.g., the Federalist Farmer) that hearken back to Roman styles of authorship. ${ }^{14}$ The Roman conceptions of republican government did of course include the importance of deliberation in public affairs, but it was only one strand in a many-colored tapestry. The choice of proper government structures also was very much a part of the overall picture:15 a strong executive; a Senate, with long terms; a plebeian body with short terms. It is no accident that our Constitution precisely follows this structure with President, Senate, and House. But these republican institutions were a means to an end, and that end had in large measure to do with the preservation of property in the broad Lockean sense. ${ }^{16}$

13. For the most detailed account of the classical origins of republican thought see generally M.N.S. Sellers, American Republicanism: Roman Ideology in the United States Constitution (1994).

14. See id. at 8-10.

15. As Sellers explains:

Americans often disagreed about the lessons of history, and how to avoid Rome's fate. But they all shared a basic conception of the republic, which they inherited from Rome, and the Roman authors they had read in school. This included: (1) pursuit of justice and the common good, through (2) the rule of law, under (3) a mixed and balanced goverument, comprising (4) a sovereign people, (5) a deliberative senate and (6) an elected magistracy. Americans in every faction endorsed this basic conception of republican government and the patrician vision of (7) ordered liberty and (8) the public virtue it sought to preserve.

Id. at 6.

16. See id. at 34, noting that according to John Adams, the "basic 'spirit of republics' [encompasses] . . . the rule of law, checks and balances, security of property, religious toleration, and personal liberty." (quoting 1 John Adams, A Defence of the Constitutions of Government of the United States of America i-ii (photo. reprint 1979) (1797)). 


\section{A Historical Counterattack}

The question then arises whether any of the history to which Flaherty refers alters this fundamental balance between the Takings Clause and the legislative power. The answer to that question has to be no. Start with Blackstone's bold and admirable declaration that

[S]o great moreover is the regard of the law for private property, that it will not authorize the least violation of it; no, not even for the general good of the whole community. If a new road, for instance, were to be made through the grounds of a private person, it might perhaps be extensively beneficial to the public; but the law permits no man, or set of men, to do this without consent of the owner of the land. In vain may it be urged, that the good of the individual ought to yield to that of the community; for it would be dangerous to allow any private man, or even any public tribunal, to be the judge of this common good, and to decide whether it be expedient or no. Besides, the public good is in nothing more essentially interested, than in the protection of every individual's private rights, as modelled by the municipal law. In this, and similar cases the legislature alone can, and indeed frequently does, interpose, and compel the individual to acquiesce. But how does it interpose and compel? Not by absolutely stripping the subject of his property in an arbitrary manner; but by giving him a full indemnification and equivalent for the injury thereby sustained. The public is now considered as an individual, treating with an individual for an exchange. All that the legislature does is to oblige the owner to alienate his possessions for a reasonable price; and even this is an exertion of power, which the legislature indulges with caution, and which nothing but the legislature can perform. ${ }^{17}$

To my unpracticed eye, this wonderful passage captures the rationale of the Takings Clause. But it surely does not answer all questions about its scope, and could be given a narrow interpretation. Flaherty notes, for example, that it is hardly clear whether "Blackstone is talking about a right that is judicially enforceable or merely aspirational." 18 But what of it? Blackstone was writing in the English tradition where the dominance of Parliament was assumed. Incorporate those same sentiments imto a takings clause on American soil, and the answer is pretty clear-unless we want to attack head-on the entire institution of judicial review. Blackstone's passage also is confined only to the outright dispossession of property by state action, as by taking land for a public highway. He thus speaks exclusively of how the doctrine works, in practice, "to oblige the owner to alienate his possession for a reasonable price."

So what should be done of regulation that falls short of dispossession, the giant question of "regulatory takings"? In my view, the answer is

17. 1 William Blackstone, Commentaries *135.

18. Flaherty, supra note 1, at 562. 
that so long as the political risks associated with such behavior are identical to those of outright dispossession, then the legal response should be the same. Therefore, what is distinctive about these cases is not that they are beyond constitutional scrutiny, but that they are more likely to benefit and bind alike, so that compensation will be implicit in the legislative scheme itself. ${ }^{19}$

One can freely acknowledge that Blackstone did not see how or why his principle extended to those forms of government regulation. Yet it is equally important to recoguize that even our Supreme Court, while no champion of the Takings Clause, does not immunize all regulations from takings challenges. Thus Lucas $v$. South Carolina Coastal Council recently affirmed that regulation amounted to a compensable taking whenever it deprived its owner of "all 'economically beneficial uses" of the land. ${ }^{20}$ Nothing in Blackstone blocks that result, nor the further insistence that partial restrictions on land use should in principle be compensable as well.

Flaherty attempts to bolster his narrow reading of Blackstone by referring to Forrest McDonald's Novus Ordo Seclorum: "But the crucial fact is that ownership did not include the absolute right to buy or sell one's property in a free market; that was not part of the scheme of things in eighteenth-century England and America."21 But once again the footnote to the quoted text is less decisive than the textual assertion. The leading forms of regulation in England prohibited forestalling, regrating and engrossing, ${ }^{22}$ practices that involved the large purchase of corn or other essential commodities with a view toward forcing their price up on resale. Even my expansive view of the Takings Clause leaves the state room to regulate inonopoly power. Similarly, the regulation of common carriers and innkeepers counteracted their previously monopolistic positions by requiring that all comers be taken without discrimination. ${ }^{23}$

There are of course inore difficult cases, such as the usury laws, where Flaherty is on stronger ground. Yet even in this setting, the nature of the justifications proffered could have a critical effect on the overall analysis. To the extent that these laws stemmed from traditional religious opposition to money-lending, they might have fallen within a seventeenth-century conception of the police power. To the extent that they responded to limited entry into capital markets, they could be regarded (weakly) as responses to a monopoly problem. Yet even here the ultimate question is not what was done at that time, but whether those statutes were in tension with the Constitution as adopted, as they surely are if the

19. See Lucas v. South Carolina Cóastal Council, 112 S. Ct. 2886, 2895 (1992); Epstein, Takings, supra note 3, at 195-215.

20. Lucas, 112 S. Ct. at 2893.

21. McDonald, supra note 10 , at 14 .

22. Id. at 14 n.8.

23. See Allnutt v. Inglis, 104 Eng. Rep. 206 (K.B. 1810), discussed in Epstein, Takings, supra note 3 , at 168 n. 15 . 
applicable test is, as McDonald stresses, "offenses against public trade."24 Surely, one could not say that the passage of a usury statute would justify the total prohibition on interest under a modern statute of general application, so the tension between the Takings Clause and economic regulation still has to be faced, and to do that McDonald's history offers us an. assemblage of practices, but no consistent theory.

Finally, in contexts apart from property, there is great suspicion of any claim that whatever forms of regulation were permissible in 1789 are permissible today. In Bowers $v$. Hardwick, Justice White upheld the Georgia sodomy statute, saying: "Proscriptions against that conduct have ancient roots. Sodomy was a criminal offense at common law and was forbidden by the laws of the original 13 States when they ratified the Bill of Rights." ${ }^{25}$ But his opinion was less persuasive than Justice Blackmun's claim in dissent that the individual liberty interest had to be respected absent a showing of harm to either third parties or the parties who engaged in the practice, neither of which was shown in the case. ${ }^{26}$ Surely it is worth noting that Blackmun's framework is scarcely distinguishable from the approach that I take towards the takings question: a strong presumption of individual independence from the government that can be overridden under the police power only by showing dangers to others.

Finally, it is instructive to consider Gordon Wood, whose recent book traces the elements of the revolution in American thought between 1760 and $1790 .{ }^{27}$ His social history is less focused on property rights than McDonald's treatment; virtually all of Wood's fire is directed to the social attitudes that influenced the transition from monarchy to republicanism to democracy, made all the more remarkable because it was brought about wholly without the kind of internal violence that characterized the French Revolution. The Takings Clause and the Contract Clause are not topics on Wood's intellectual agenda. He thus refers briefly to the Contract Clause, ${ }^{28}$ and to the problem of eminent domain. ${ }^{29}$ But for our purposes, the critical question is whether the transformation in attitude toward legislative composition dilutes the protection of property rights under the Federal Constitution. Yet if the sole motivating feature of American constitutional thought were the creation of an ongoing representative government, wedded to the belief in a deliberative democracy, then why include the Contract Clause in the original Constitution, and the Takings Clause in the Bill of Rights? ${ }^{30}$ The radical republicans

24. Epstein, Takings, supra note 3, at 14.

25. Bowers v. Hardwick, 478 U.S. 186, 192 (1986).

26. See id. at 203 n.2., 209 (Blackmun, J., dissenting).

27. See Gordon S. Wood, The Radicalism of the American Revolution (1992).

28. See id. at $316,322$.

29. See id. at $188,322,422$ n. 40 .

30. Subsequently, why include them in state constitutions? Wood writes:

In 1776 most of the revolutionary state constitutions did not provide for just compensation for the public taking of private property; but, following the adoption of the Fifth Amendment to the Federal Constitution in 1791, this 
should have been able to beat back both provisions. Yet, as Herbert Storing has pointed out, for all their differences both the Federalists and Antifederalists shared the belief that the protection of private property was at least one of the legitimate ends of government. ${ }^{31}$

One clear way to see this affinity is to note the overlap between Federalist and Republican themes at the time of the Constitution. Thus the Federalists were worried about how factions could take over the reins of government for their own benefit. ${ }^{32}$ And what would they do with that power? Among other things, take the property of their fellow citizens, say by taxation, and turn it to their own advantage. A parallel theme of republican thought centered about the problem of corruption, which raises the specter that certain individuals will yield to private temptations while in public office. And what would corrupt public officials do? A good guess is to take the property of their fellow citizens, be it by bribes from their constituents or by putting their hands in the public till. And what is all this but a taking of private property for their own advantage?

In this short essay I cannot develop these themes fully, but Flaherty's own use of historical sources can be used to make the basic point. Thus Flaherty points to the work of John Phillip Reid: "In particular, [Reid argues] that neither Locke nor 'natural law' framed American constitutional discourse." 33 In opposition to natural law, Reid stresses the role of custom in the formation of legal entitlements. Reid's point hardly demands any rethinking of the constitutional status of property. The tension between the first possession rule as a principle of positive law and one of custom surfaced throughout the nineteenth century. ${ }^{34}$ What Reid has done is to make property rights more secure by virtue of their customary basis. Is there any reason why, once these rights are established under customary law, they should not be protected under the Takings

provision was explicitly added in nearly all the constitutions of states subsequently admitted to the Union. In the following years, where such a specific reference to just compensation remained absent from the constitutions of the original states, judicial interpretation often inserted it.

Id. at 422 n. 40.

31. See The Federalist No. 44 (James Madison); Storing, supra note 10, at 15, 83 n.7; see also Jennifer Nedelsky, Confining Democratic Politics: Anti-Federalists, Federalists, and the Constitution, 96 Harv. L. Rev. 340 (1982) (book review) (questioning whether, when read together, the thought of the Antifederalists and the history of the Marshall Court can create a broader conception of democracy than that implicit in the Constitution). For my own comments on Storing's work, see Richard A. Epstein, Beyond the Rule of Law: Civic Virtue and Constitutional Structure, 56 Geo. Wash. L. Rev. 149, 162-71 (1987).

32. See The Federalist No. 10 (James Madison) (an obvious citation but still the most cogent one).

33. Flaherty, supra note 1 , at 544 .

34. See, e.g., Swift v. Gifford, 23 F. Cas. 558 (D.C.D. Mass. 1872) (No. 13,696) (relying on custom); The Reeside, 20 F. Cas. 458, 459 (C.C.D. Mass. 1837) (No. 11,657) (limiting the use of custom in contractual settings). For my qualified support of the customary position, see Richard A. Epstein, Possession as the Root of Title, 13 Ga. L. Rev. 1221, 1230-31 (1979). 
Clause? After all, if $\mathrm{X}$ acquires property by adverse possession from $\mathrm{Y}$, it hardly follows that the state can confiscate it without compensation. Once the title is itself secure, then why worry about the jurisprudential nature of its origins?

Flaherty also tells us that "property, jury trials, personal security, and freedom from arbitrary government" were part of the non-Lockean package. But they are surely part of the Lockean package as well, given in section 138 quoted above, where the protection of property and freedom from arbitrary power are obvious themes of Locke. There is then some reason to doubt Flaherty's central conclusion: "John Phillip Reid's massive body of scholarship, in particular, challenges the claim that Lockean notions of natural property rights, still less Epstein's version of Locke, significantly fueled early American defenses of property." ${ }^{35}$ And it is surely worth noting that Reid's view of the Founding period might be overdrawn on the descriptive side as well, for as Flaherty notes in his examination of Bruce Ackerman's work, ${ }^{36}$ natural law has some staying power after all:

Though Reid strongly argues that English constitutional principles all but eclipsed American reliance on natural law, his position has yet to carry the day; nor does Ackerman rely on his work. Moreover, it is implausible that natural law dropped out of the picture after $\mathbf{1 7 7 6}$ any more than republicanism disappeared after $1787 .{ }^{37}$

So once again we are back to the obvious conclusion evident from the text of the Constitution itself: the Founders were concerned both about the structure of federal power and the protection of individual property rights.

The history then confirms what the text of the Constitution makes clear. Still wanting is a brief comment on the role that history plays in constitutional litigation. The strength of historical work is to go backwards and to set constitutional provisions against the intellectual and social backdrop of their time. Litigation goes forward, and applies texts drafted in one generation to problems that arise in the next. So the key question remains: does history give much guidance in particular disputes? For example, does the Contract Clause apply to grants made by the state?38 Does it have prospective or only retroactive application? ${ }^{39}$ Are police power and just compensation qualifications to be read into the Clause? ${ }^{40}$ Does the Clause only protect the basic contract right, or also

35. Flaherty, supra note 1 , at 544,564 .

36. See I Bruce Ackerman, We the People (1991).

37. Flaherty, supra note 1 , at 588 .

38. See Trustees of Dartmouth College v. Woodward, 17 U.S. (4 Wheat.) 517, 654 (1819); Fletcher v. Peck, 10 U.S. (6 Cranch) 87, 137 (1810).

39. See Ogden v. Saunders, 25 U.S. (12 Wheat.) 212, 215 (1827).

40. See, e.g., Home Bldg. \& Loan Ass'n v. Blaisdell, 290 U.S. 398, 425-27 (1934); West River Bridge Co. v. Dix, 47 U.S. 507, 532 (1848). 
limit the power of the state to change the available remedy for breach? ${ }^{41}$ Similarly, under the Takings Clause, questions arise about the distinction between mere regulations and compensable takings, ${ }^{42}$ the use of the disproportionate impact test, ${ }^{43}$ and the scope of the police power. ${ }^{44}$ The analytic approach that I espouse allows us to move more easily from the original text to these conceptual challenges than does an alternative historical approach that tries to bring coherence to the future from a close attention to the past. Even so, coming to cloture on this controversy cannot be done finally and the choice of method may well vary with the clarity of the text and the strength of the historical materials. Professor Flaherty is to be commended for raising this issue once again in sharp relief. While I disagree with his methodological emphasis, I applaud him for pressing forward with the debate in a constructive fashion.

41. See, e.g., City of El Paso v. Simmons, 379 U.S. 497, 508-09 (1965).

42. Pennsylvania Coal Co. v. Mahon, 260 U.S. 393, 412-16 (1922).

43. Armstrong v. United States, 364 U.S. 40, 49 (1960).

44. Mugler v. Kansas, 123 U.S. 623, 674 (1887). 